\title{
Assimilatory detoxification of herbicides by Delftia acidovorans MC1: induction of two chlorocatechol 1,2-dioxygenases as a response to chemostress
}

\author{
Dirk Benndorf and Wolfgang Babel
}

\begin{abstract}
Author for correspondence: Wolfgang Babel. Tel: +49 341235 2225. Fax: +49 3412352247. e-mail: babel@umb.ufz.de
\end{abstract}

UFZ - Centre for Environmental Research Leipzig-Halle, Department of Environmental Microbiology, PF 500135, 04301 Leipzig, Germany

\begin{abstract}
Proteome analysis of bacteria that can detoxify harmful organic compounds enables the discovery of enzymes involved in the biodegradation of these substances and proteins that protect the cell against poisoning. Exposure of Delftia acidovorans MC1 to 2,4-dichlorophenoxypropionic acid and its metabolites 2,4-dichlorophenol and 3,5-dichlorocatechol during growth on pyruvate as a source of carbon and energy induced several proteins. Contrary to the general hypothesis that lipophilic or reactive compounds induce heat shock or oxidative stress proteins, no induction of the GroEL, DnaK and AhpC proteins that were used as markers for the induction of heat shock and oxidative stress responses was observed. However, two chlorocatechol 1,2-dioxygenases, identified by amino terminal sequence analysis, were induced. Both enzymes catalyse the conversion of 3,5-dichlorocatechol to 2,4-dichloro-cis,cis-muconate indicating that biodegradation is a major mechanism of resistance in the detoxifying bacterium $D$. acidovorans MC1.
\end{abstract}

Keywords: resistance mechanism, degradation, chlorophenoxy herbicides, 2D-PAGE

\section{INTRODUCTION}

The herbicide 2-(2,4-dichlorophenoxy)propionic acid is used in crop control. The biodegradation of chlorophenoxy acid herbicides by microbial communities was first observed several years ago (Duxbury et al., 1970; Evans et al., 1971; Pemperton \& Fisher, 1977; Kilpi, 1980). Since then, various species have been isolated which are able to use at least one of these compounds as the sole source of carbon and energy (Pieper et al., 1988; Horvath et al., 1990). The enzymes and the corresponding genes involved in the biodegradation pathway have been well described in some species (Fukumori \& Hausinger, 1993; Kaphammer et al., 1990). The first step of biodegradation is often catalysed by a 2oxoglutarate dependent dioxygenase, which is encoded by the gene $t f d A$. The $t f d B C D E$ genes which, like $t f d A$,

Abbreviations: 3,5-DCC, 3,5-dichlorocatechol: 2,4-DCP, 2,4-dichlorophenol; 2,4-DCPP, 2,4-dichlorophenoxypropionic acid; IPG, immobilized $\mathrm{pH}$ gradient.

The SWISS-PROT accession numbers for the sequences reported in this paper are P83115, P83116 and P83117. belong to the $t f d$ gene cluster, catalyse ortho-cleavage of the aromatic ring of the first metabolite dichlorophenol and the following dechlorination. However, this knowledge alone seems to be insufficient to explain the low conversion rates of chlorophenoxy acids observed at polluted sites. Therefore, current research is focused on determining the effects of unfavourable environmental factors on the biodegradation rate and on discovering mechanisms that stabilize the biocatalysts. One unfavourable factor could be growth on 2,4-dichlorophenoxyacetic acid $(2,4-\mathrm{D})$ itself, which causes the depletion of ATP (Müller et al., 1997). In addition, the presence of 2,4-D induces the synthesis of the heat-shock proteins DnaK and GroEL in Burkholderia sp. YK-2 (Cho et al., 2000), indicating the importance of stress proteins for adaptation. These results are consistent with the established fact that detoxifying bacteria respond to chemostress by inducing stress proteins (Lupi et al., 1995; Uchiyama et al., 1999), as do many other bacteria (Blom et al., 1992; van Dyk et al., 1994). Previous studies have shown heat-shock proteins to be induced by a variety of mainly hydrophobic compounds and these chaperones may defend cells against the toxic effects of such compounds (Benndorf et al., 1999). An example of an 
active protection mechanism is the induction of the oxidative stress response in Acinetobacter calcoaceticus, which increases the organism's resistance to catechol by detoxifying reactive oxygen species released by redox cycling (Benndorf et al., 2001). The induction of further groups of proteins associated with responses to starvation (Blom et al., 1992), osmotic shock and $\mathrm{pH}$ shock (Vasseur et al., 1999) has also been observed.

Our intention here was to study mechanisms of the bacterium Delftia acidovorans MC1, which is able to utilize chlorophenoxy acids (Müller et al., 1999), to detoxify 2,4-dichlorophenoxypropionic acid (2,4DCPP), 2,4-dichlorophenol (2,4-DCP) and 3,5-dichlorocatechol (3,5-DCC). For this purpose we analysed the short-term response by 2D-electrophoresis during growth on the non-toxic growth substrate pyruvate.

\section{METHODS}

Bacterial strain, growth and stress conditions. Delftia acidovorans MC1 (formerly known as Comamonas acidovorans MC1) was used for this study. It was continuously grown in a fermenter (Braun) with a working volume of $1.5 \mathrm{l}$. The growth temperature was $30^{\circ} \mathrm{C}$, the dissolved oxygen concentration ranged from 70 to $95 \%$ and the $\mathrm{pH}$ was maintained at $7 \cdot 0$ by automatic titration with $0.1 \mathrm{M} \mathrm{KOH}$ or $0.25 \mathrm{M} \mathrm{H}_{2} \mathrm{SO}_{4}$, as appropriate. The cultivation started with a batch culture on $3 \mathrm{~g}$ sodium pyruvate $\mathrm{l}^{-1}$ as the sole source of carbon and energy in minimal medium to late exponential growth phase (Müller \& Babel, 1986). Afterwards, the culture was grown chemostatically on $2 \mathrm{~g}$ sodium pyruvate $\mathrm{l}^{-1}\left(\mathrm{~s}_{0}\right)$ with a dilution rate (D) of $0 \cdot 2 \mathrm{~h}^{-1}$ for at least $20 \mathrm{~h}$. This culture was harvested from the fermenter and $2 \mathrm{~g}$ sodium pyruvate $\mathrm{l}^{-1}$ was added. The culture was then divided into $50 \mathrm{ml}$ portions that were placed in $500 \mathrm{ml}$ shake flasks and exposed for $1.5 \mathrm{~h}$ to the following stress factors: 2,4-DCPP (Sigma; at least 95\% purity), 2,4DCP (Sigma; at least $99 \%$ purity) and 3,5-DCC (Promochem; 95-99\% purity) were added at a range of concentrations between 10 and $1000 \mu \mathrm{M}$; heat shock at $41^{\circ} \mathrm{C}$; and $\mathrm{H}_{2} \mathrm{O}_{2}$ (added in nine $1 \mathrm{mM}$ batches at 10 min intervals). All stress experiments were run in duplicate and growth was measured spectrophotometrically by monitoring optical density at $700 \mathrm{~nm}$.

Sample preparation and protein determination. The bacteria were harvested by centrifugation at $4{ }^{\circ} \mathrm{C}$ for $10 \mathrm{~min}$ at $8000 \mathrm{~g}$ and washed twice with a $50 \mathrm{mM}$ Tris/ $\mathrm{HCl}$ buffer $(\mathrm{pH} 7 \cdot 5)$ containing $0 \cdot 1 \mathrm{mg}$ chloramphenicol ml $\mathrm{ml}^{-1}$ and $1 \mathrm{mM}$ PMSF. Lysis buffer $(50 \mu \mathrm{l} ; 50 \mathrm{mM}$ Tris $/ \mathrm{HCl} \mathrm{pH} 7 \cdot 5$ containing $2 \%$, $\mathrm{w} / \mathrm{v}, \mathrm{SDS})$ was added to $50 \mu \mathrm{l}$ of the washed cell suspensions and the cells were lysed by incubation at $60^{\circ} \mathrm{C}$ for $5 \mathrm{~min}$. After adding $1 \mathrm{ml} 50 \mathrm{mM}$ Tris $/ \mathrm{HCl}$ buffer $\mathrm{pH} 7 \cdot 5$ containing $1 \mu \mathrm{l}$ Benzonase $\mathrm{ml}^{-1}$ (Merck), $0 \cdot 1 \mathrm{mg} \mathrm{MgCl}_{2} \mathrm{ml}^{-1}$ and $1 \mathrm{mM}$ PMSF the mixture was incubated at $37^{\circ} \mathrm{C}$ for $10 \mathrm{~min}$. Unbroken cells and cell debris were removed by centrifugation for $10 \mathrm{~min}$ at $8000 \mathrm{~g}$ and $4{ }^{\circ} \mathrm{C}$. The protein content was determined as described by Holtzhauer \& Hahn (1988).

2D-electrophoresis. Cell-free extracts containing $50 \mu$ g protein for analytical separations or $2000 \mu \mathrm{g}$ for micropreparative separations were precipitated by adding 5 vols ice-cold acetone, incubating for $20 \mathrm{~min}$ on ice and centrifuging at $12000 \mathrm{~g}$ for $10 \mathrm{~min}$. The precipitated proteins were resuspended in $100 \mu \mathrm{l}$ resolubilizing solution containing $8 \mathrm{M}$ urea, $2 \%(\mathrm{v} / \mathrm{v})$ Triton X-100, $2 \%(\mathrm{w} / \mathrm{v})$ CHAPS, $0.5 \%$ (v/v) IPG (immobilized $\mathrm{pH}$ gradient) $\mathrm{pH} 3-10$ NL Buffer (Pharmacia), $65 \mathrm{mM}$ dithioerythritol and $0.01 \%(\mathrm{w} / \mathrm{v})$ bromophenol blue. After agitating for $10 \mathrm{~min}, 400 \mu \mathrm{l}$ of a rehydrating solution containing $8 \mathrm{M}$ urea, $2 \%(\mathrm{v} / \mathrm{v})$ Triton X-100, $0.5 \%(\mathrm{v} / \mathrm{v})$ IPG pH 3-10 NL Buffer (Pharmacia) and $65 \mathrm{mM}$ dithioerythritol was added, and the resulting solution was centrifuged at $12000 \mathrm{~g}$ for $30 \mathrm{~min}$ to remove precipitates.

Samples of the solution $(450 \mu \mathrm{l})$ were loaded on $18 \mathrm{~cm}$ long Immobiline DryStrip pH 3-10 NL gels for equilibration overnight. After equilibration the proteins were separated by isoelectric focusing using an IPG Phore electrophoresis unit (Pharmacia). The gels were run for a total of $100 \mathrm{kVh}$ for analytical separations and $240 \mathrm{kVh}$ for preparative separations. After the isoelectric focusing, the gels were equilibrated as described by Benndorf et al. (1999) and the equilibrated gels were stored at $-18{ }^{\circ} \mathrm{C}$ until use in second dimension electrophoresis.

For the second dimension, the gels were loaded into a layer of $0.5 \%(\mathrm{w} / \mathrm{v})$ agarose in separation buffer at $80{ }^{\circ} \mathrm{C}$ on $9-18 \%$ $(\mathrm{w} / \mathrm{v})$ polyacrylamide gradient gels $(240 \times 200 \times 1 \mathrm{~mm})$. The gels were run overnight in a Dalt electrophoresis unit (Hoefer) at a voltage of $100 \mathrm{~V}$ and a temperature of $12^{\circ} \mathrm{C}$. After completion of SDS-PAGE, the gels were fixed, silver stained as described by Blum et al. (1987) and dried in a stream of unheated air from a GelAir Dryer (Bio-Rad).

Western blotting. The gels were electroblotted overnight onto PVDF (Bio-Rad) membranes and nitrocellulose membranes for immunochemical staining. The blotting was carried out overnight in the Dalt electrophoresis unit (Hoefer) at a current of $600 \mathrm{~mA}$ and a temperature of $12{ }^{\circ} \mathrm{C}$ in $10 \mathrm{mM}$ CAPS buffer pH 11 containing $10 \%$ (v/v) methanol (Jin \& Cerletti, 1992). The PVDF membranes were stained with $0 \cdot 1 \%(\mathrm{w} / \mathrm{v})$ Coomassie blue in $50 \%(\mathrm{v} / \mathrm{v})$ methanol and $10 \%(\mathrm{v} / \mathrm{v})$ acetic acid for $10 \mathrm{~min}$. After destaining the membranes with several changes of $50 \%(\mathrm{v} / \mathrm{v})$ methanol and $10 \%(\mathrm{v} / \mathrm{v})$ acetic acid the membranes were dried and stored at $-18{ }^{\circ} \mathrm{C}$. Spots of interest were excised and subjected to $\mathrm{N}$-terminal amino acid sequencing using a model $473 \mathrm{~A}$ protein sequencer (Applied Biosystems).

The proteins on the nitrocellulose membranes were stained with $0.2 \%(\mathrm{w} / \mathrm{v})$ Ponceau $\mathrm{S}$ in $3 \%(\mathrm{w} / \mathrm{v})$ TCA and destained with water. For immunochemical stains an Immun-Blot Assay Kit (Bio-Rad) was used with a secondary goat anti-rabbit antibody linked to horseradish peroxidase. The primary antibodies, polyclonal anti-GroEL and anti-HSP 70 from rabbit, were obtained from Sigma and Upstate Biotechnology, respectively.

Comparison of 2D protein patterns. The dried gels were scanned with a UMAX Power Look 2000 Scanner with an eight bit dynamic range and 200 d.p.i. resolution. The images were analysed and compared by Phoretix 2D 5.01 software (NonLinear Dynamics). For comparing protein patterns we used only spots that were detected in both gels of the duplicated experiments. Protein spots with a twofold, or greater, intensity than the corresponding spots in control gels were considered to be amplified, and spots which were observed following imposition of stress conditions, but were not in the control protein pattern, were considered to represent newly synthesized proteins. Molecular mass and pI were calibrated using internal standards defined by calibration with the 2D SDS-PAGE Standards kit (Bio-Rad). 
Table 1. Influence of chemicals on growth of D. acidovorans MC1 with pyruvate

The growth rate of the control after transfer in batch culture was $0.65 \mathrm{~h}^{-1}$.

\begin{tabular}{|cccc|}
\hline Concn $(\mu \mathrm{M})$ & \multicolumn{3}{l}{ Growth rate $(\%)$ of control in the presence of: } \\
\cline { 2 - 4 } & 2,4-DCPP & 2,4-DCP & 3,5-DCC \\
& & & \\
10 & 100 & 101 & 101 \\
100 & 85 & 94 & 52 \\
1000 & 12 & 12 & 4 \\
\hline
\end{tabular}

\section{RESULTS}

\section{Influence of 2,4-DCPP and its metabolites on growth rate}

The precultivation of $D$. acidovorans provided us with a reproducible culture to start the stress experiments. After the transfer into batch cultures there was no lagphase detectable and the observed growth rate of the control was $0.65 \mathrm{~h}^{-1}$, which corresponds to approximately one doubling in $1.5 \mathrm{~h}$. The presence of 2,4-DCPP, 2,4-DCP and 3,5-DCC caused a reduction in the growth rate of D. acidovorans MC1 to as little as $4 \%$ of control rates, depending on the concentration of the compounds
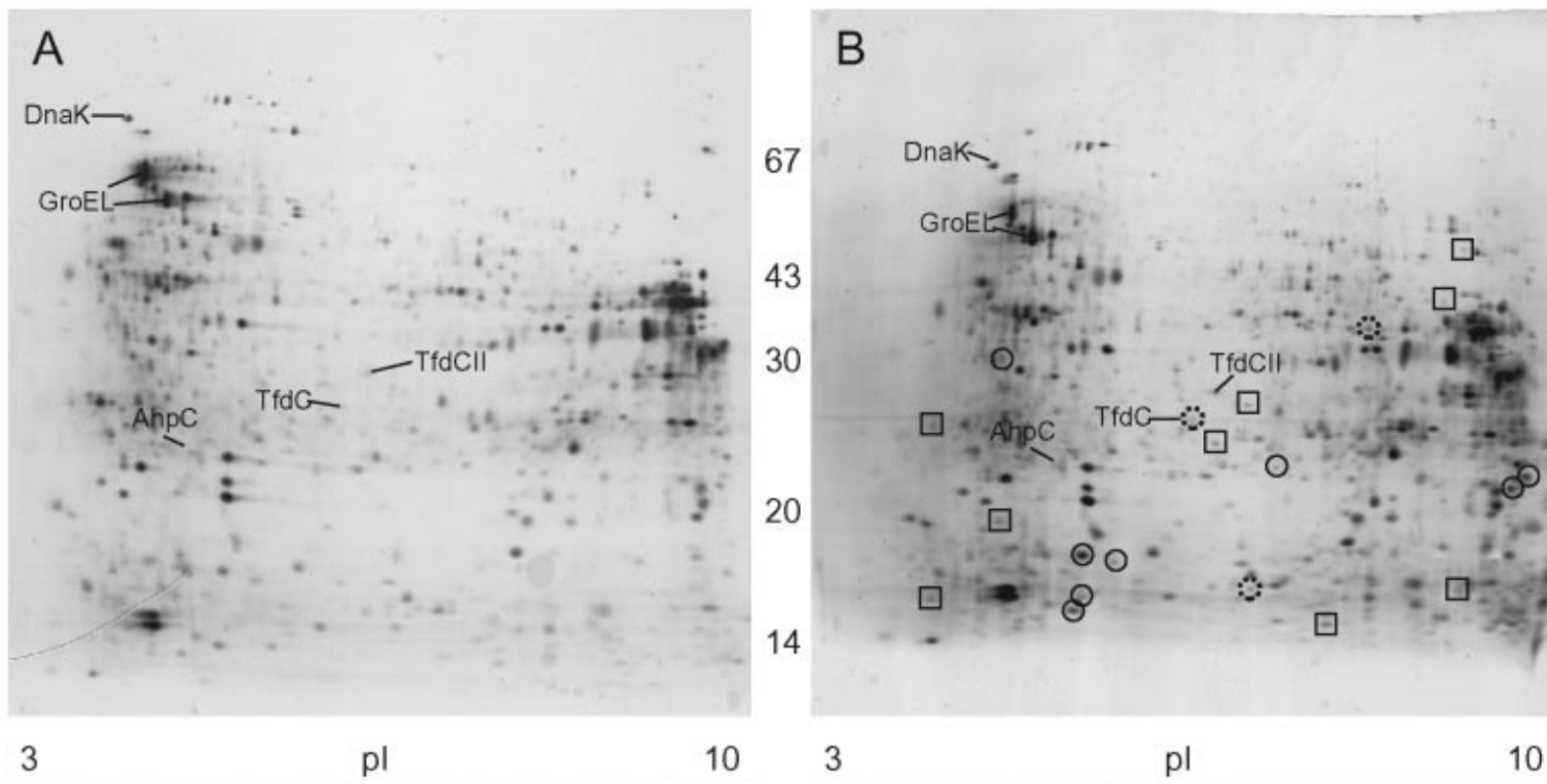

3

$\mathrm{pl}$

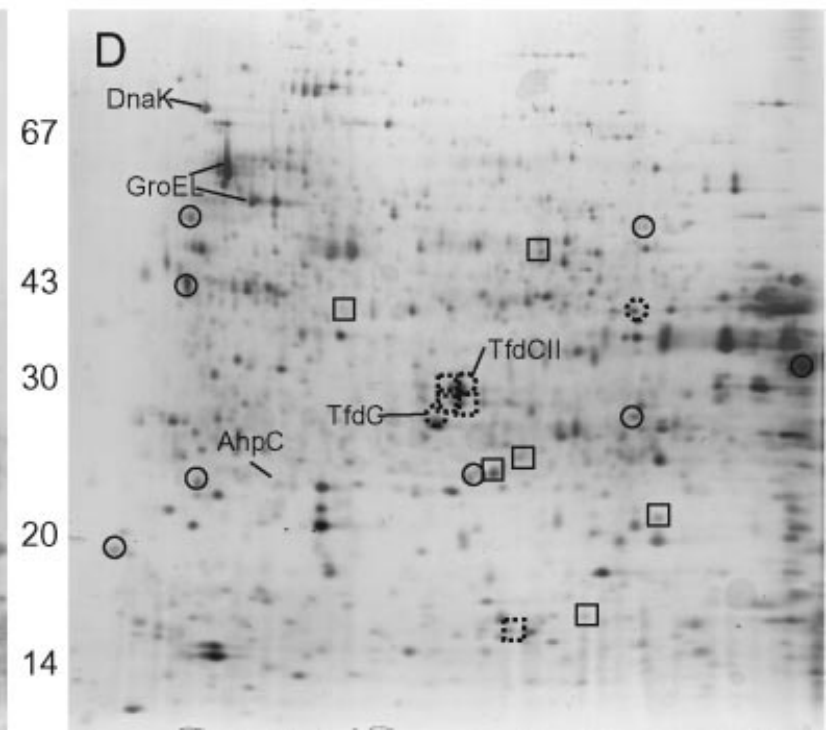

Fig. 1. 2D protein patterns of Delftia acidovorans MC1 after treatment with chemicals. A, control; B, $100 \mu \mathrm{M}$ 2,4-DCPP; C, $100 \mu \mathrm{M}$ 2,4-DCP; D, $100 \mu \mathrm{M}$ 3,5-DCC. Circled spots, more than twofold amplified proteins; boxed spots, new proteins; spots surrounded by dotted lines, proteins induced by at least two chemicals. 

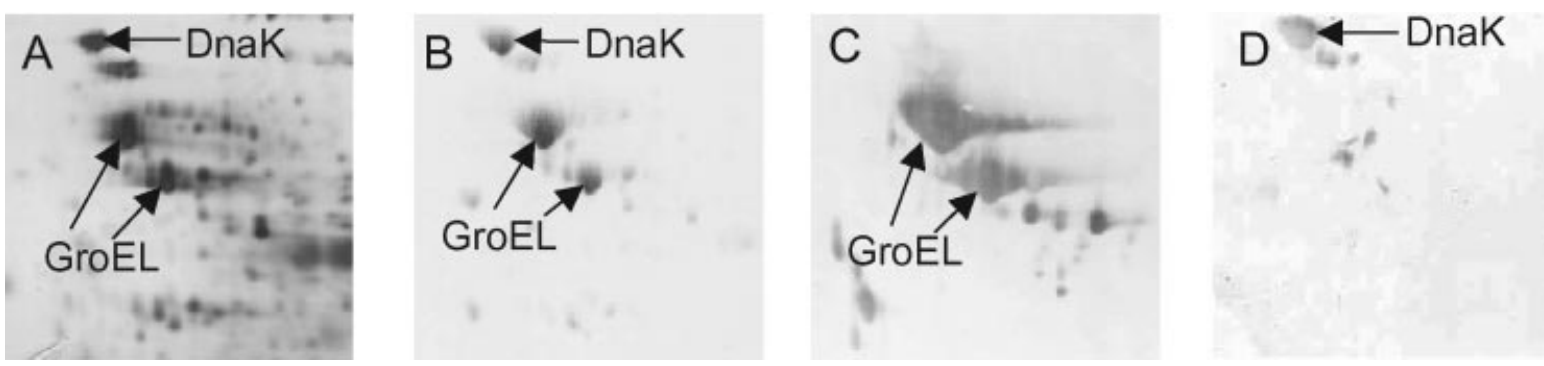

Fig. 2. Detection of the heat-shock proteins DnaK and GroEL of $D$. acidovorans MC1 by immunostaining. A, silver stained protein pattern; B, Ponceau S stained protein pattern; C and D, immunochemical stains of protein patterns.

Table 2. N-terminal sequences of identified proteins of $D$. acidovorans MC1

\begin{tabular}{|c|c|c|c|c|}
\hline $\begin{array}{l}\text { Accession } \\
\text { no. }\end{array}$ & Protein & Function & $\begin{array}{c}\text { Molecular } \\
\text { mass }(\mathrm{kDa}) ; \\
\text { pI }\end{array}$ & Sequence \\
\hline & & & & $\begin{array}{lllll}1 & 5 & 10 & 15 & 20\end{array}$ \\
\hline \multirow[t]{2}{*}{ P83115 } & TfdC & $\begin{array}{l}\text { Chlorocatechol } \\
\text { 1,2-dioxygenase I }\end{array}$ & $28 \cdot 6 ; 5 \cdot 64$ & MN E R V K Q V A S A L V D A I Q K T L T E Q R V \\
\hline & & & & $\begin{array}{llllll}1 & 5 & 10 & 15 & 20 & 25\end{array}$ \\
\hline P83116 & TfdCII & $\begin{array}{l}\text { Chlorocatechol } \\
\text { 1,2-dioxygenase II }\end{array}$ & $30 \cdot 8 ; 5 \cdot 69$ & M K N P R V H E I A T A I D A V R K V L V D H Q \\
\hline & & & & $\begin{array}{llllll}1 & 5 & 10 & 15 & 20 & 25\end{array}$ \\
\hline P83117 & AhpC & $\begin{array}{l}\text { Alkyl- } \\
\text { hydroperoxide } \\
\text { reductase protein } \\
\text { C22 }\end{array}$ & $25 \cdot 7 ; 5 \cdot 22$ & S V I N T Q I K P F K T Q A F K N G K F I E V T E \\
\hline
\end{tabular}

(Table 1). 2,4-DCPP $(100 \mu \mathrm{M})$ and $100 \mu \mathrm{M} 2$,4-DCP had similar effects on growth, yielding growth rates of $85 \%$ and $94 \%$ of control rates, respectively, while at $1000 \mu \mathrm{M}$ both compounds reduced growth to $12 \%$ of control rates. Growth was reduced to half of the control rate in the presence of $100 \mu \mathrm{M} 3,5$-DCC and almost totally inhibited in the presence of $1000 \mu \mathrm{M} 3,5$-DCC.

\section{Influence of DCPP and its metabolites on protein synthesis}

Treatment of D. acidovorans with $100 \mu \mathrm{M}$ 2,4-DCPP, 2,4-DCP and 3,5-DCC during growth on pyruvate resulted in the repression of some proteins (not shown) and in the induction of 58 proteins which were amplified at least twofold or were newly synthesized (Fig. 1). Only two proteins were induced from non-detectable levels by all the compounds, but we detected 50 specific proteins that were amplified by one of these compounds. In addition, a group of four proteins were induced after treatment with 2,4-DCP and 3,5-DCC (but not 2,4DCPP) and a further two were induced following treatment with 2,4-DCPP and 3,5-DCC. To determine whether the induced proteins included the heat-shock proteins DnaK or GroEL we assessed their levels in
Western blots with polyclonal antibodies (Fig. 2). We detected both proteins (identifying two main GroEL spots with molecular masses of $59 \cdot 1$ and $53 \cdot 0 \mathrm{kDa}$, and isoelectric points of 4.94 and $5 \cdot 05$, respectively, and one main spot of DnaK with a molecular mass of $70 \cdot 2 \mathrm{kDa}$ and an isoelectric point of 4.79), and measured induction in heat-shocked cells (up to a threefold level). However, we observed no significant induction of these proteins after treatment with the chemicals (data not shown). Moreover, levels of the oxidative stress protein alkylhydroperoxide reductase $\mathrm{C}(\mathrm{AhpC})$, which has been identified as a major component of the response of $D$. acidovorans MC1 to hydrogen peroxide by electrophoretic analysis and amino-terminal sequencing (Table 2), remained unchanged following treatment with 2,4DCPP, 2,4-DCP and 3,5-DCC (not shown). Further sequencing of two proteins, one of which was generally induced by treatment with all the chemicals tested and the other of which was only induced by treatment with 2,4-DCP and 3,5-DCC, led to the identification of two chlorocatechol 1,2-dioxygenases (TfdC and TfdCII) in D. acidovorans MC1 (Table 2). Fragments of both enzymes have already been detected in this strain by DNA sequencing of PCR products (Müller et al., 2001). The strongest induction of both enzymes was observed 


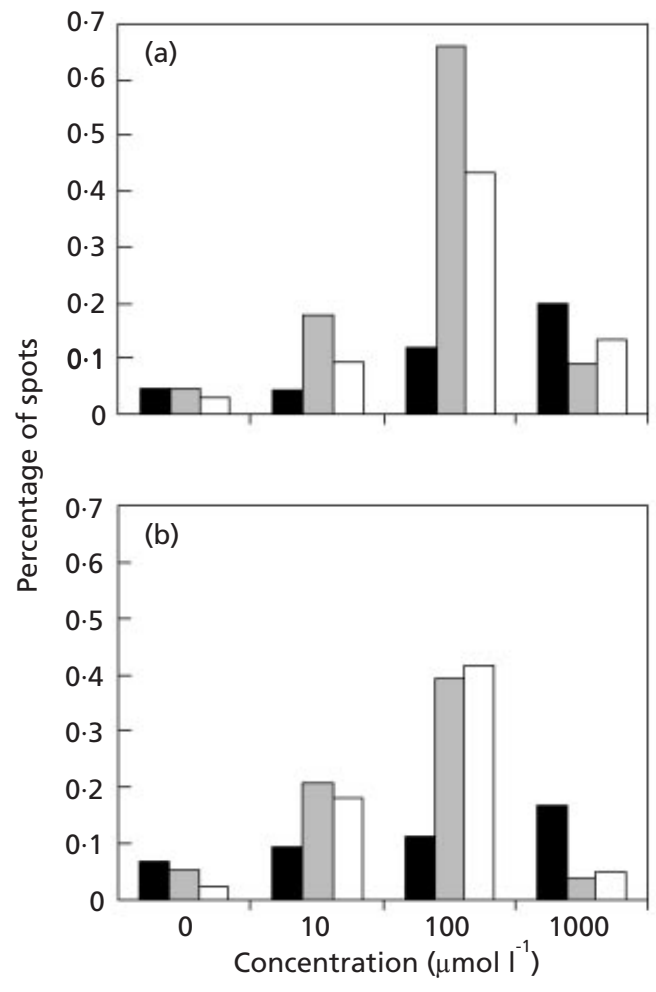

Fig. 3. Induction ratios of the chlorocatechol 1,2-dioxygenases TfdC (a) and TfdCII (b) of D. acidovorans MC1. Black bars, 2,4DCPP; grey bars, 2,4-DCP; white bars, 3,5-DCC.

in response to $100 \mu \mathrm{M}$ 2,4-DCP and $100 \mu \mathrm{M}$ 3,5-DCC (Fig. 3) whereas $1000 \mu \mathrm{M}$ 2,4-DCPP was necessary to cause a small induction of both enzymes.

\section{DISCUSSION}

D. acidovorans responds to 2,4-DCPP and its first metabolites at the protein synthesis level. In this paper we focused on the induced proteins and not on the repressed proteins since we expected that they are predominantly involved in adaptive responses. Two generally induced proteins may indicate a common mechanism of resistance against compounds like 2,4DCPP, whereas the more specifically induced proteins may reflect the differences between the test compounds. The concentration of 2,4-DCPP and its metabolites which cause the strongest induction of stress proteins in $D$. acidovorans is 3- to 30-fold lower than the concentration of 2,4-D that causes their strongest induction in Burkholderia sp. YK-2 (Cho et al., 2000). The weaker induction of the chlorocatechol 1,2-dioxygenases by 2,4DCP and 3,5-DCC at $1000 \mu \mathrm{M}$ than at $100 \mu \mathrm{M}$ correlates with the pronounced reduction of growth rate that the higher concentration caused. But 2,4-DCPP seems to be a less effective inducer of both enzymes although $1000 \mu \mathrm{M}$ 2,4-DCPP inhibits the growth to the same extent. In contrast to results obtained with Burkholderia sp. YK-2 (Cho et al., 2000) and with an Escherichia coli strain harbouring a fusion of $g r p E$ and $d n a K$ heat-shock promoters with lux genes (van Dyk et al., 1994), we did not observe an increase of heat-shock proteins when we measured the proteins GroEL and DnaK after treatment with the lipophilic 2,4-DCPP and its metabolites. This was surprising and interesting insofar as a high degree of lipophilicity has proven to be a common property of chemicals that induce heat-shock proteins, e.g. primary alcohols in A. calcoaceticus 69-V (Benndorf et al., 1999, 2001). A further important property of potential stress chemicals, which may account for the induction of other groups of stress proteins, is their reactivity. For example, A. calcoaceticus $69-\mathrm{V}$ synthesizes oxidative stress proteins in response to catechol (Benndorf et al., 2001), which detoxifies reactive oxygen species generated by redox cycling (Schweigert et al., 2001). It is also noteworthy that the reactive compound 3,5-DCC induced no change in the level of alkylhydroperoxide reductase subunit $\mathrm{C}$, which is strongly induced by hydrogen peroxide. This protein is a gene product of the $o x y R$ regulon of many Gram-negative bacteria, so the failure of 3,5-DCC to induce it excludes the possibility that OxyR-dependent oxidative stress proteins are involved in the response to 2,4-DCPP and its metabolites. Instead of the synthesis of well-known stress proteins, two chlorocatechol 1,2-dioxygenases (TfdC and TfdCII), both of which are involved in the metabolism of the inducing compounds, were strongly increased in response to $100 \mu \mathrm{M} 2,4-\mathrm{DCP}$ and 3,5-DCC but only weakly induced in response to $1000 \mu \mathrm{M} 2,4-$ DCPP. The induction of both enzymes, within $1.5 \mathrm{~h}$ of treatment with these compounds during growth on pyruvate, indicates that degradation is a defence mechanism in $D$. acidovorans. The presence of a readily utilizable carbon and energy source may support the induction. The identification of further proteins involved in the degradation and assimilation of 2,4-DCPP would confirm our conclusion. Two further catabolic enzymes were assigned by isoelectric point and molecular mass (Fig. 1C) as TfdB (chlorophenol hydroxylase) and $\mathrm{TfdD}$ (chloromuconate cycloisomerase), but so far, amino terminal sequencing has been unsuccessful due to the low amounts of sample.

D. acidovorans MC1 defends against potential toxic organic compounds by inducing proteins capable of degrading these compounds. This seems to be rather the rule than an exception in micro-organisms which are resistant to hazardous organic compounds.

\section{ACKNOWLEDGEMENTS}

We would like to thank Dr P. Mak and Dr A. Dubin (BioCenter Krakow, Institute of Molecular Biology, Jagiellonian University, Krakow, Poland) for the determination of N-terminal amino acid sequences. This work has been supported by a grant from the European Commission within its Fifth Framework Programme (Project designation: HERBICBIOREM, contract no. QLK3-CT-1999-00041).

\section{REFERENCES}

Benndorf, D., Loffhagen, N. \& Babel, W. (1999). Induction of heat shock proteins in response to primary alcohols in Acinetobacter calcoaceticus. Electrophoresis 20, 781-789. 
Benndorf, D., Loffhagen, N. \& Babel, W. (2001). Protein synthesis patterns in Acinetobacter calcoaceticus induced by phenol and catechol show specificities of responses to chemostress. FEMS Microbiol Lett 200, 247-252.

Blom, A., Harder, W. \& Matin, A. (1992). Unique and overlapping pollutant stress proteins of Escherichia coli. Appl Environ Microbiol 58, 331-334.

Blum, H., Beier, H. \& Gross, H. J. (1987). Improved silver staining of plant proteins, RNA and DNA in polyacrylamide gels. Electrophoresis 8, 93-99.

Cho, Y.-S., Park, S.-H., Kim, C.-K. \& Oh, K.-H. (2000). Induction of stress shock proteins DnaK and GroEL by phenoxyherbicide 2,4-D in Burkholderia sp. YK-2 isolated from rice field. Curr Microbiol 41, 33-38.

Duxbury, J. M., Tiedje, J. M., Alexander, M. \& Dawson, J. E. (1970). 2,4-D metabolism : enzymatic conversion of chloromaleylacetic acid to succinic acid. J Agric Food Chem 18, 199-201.

Evans, W. C., Smith, B. S., Moss, P. \& Fernley, H. N. (1971). Bacterial metabolism of 4-chlorophenoxyacetate. Biochem J 122, 509-517.

Fukumori, F. \& Hausinger, R. P. (1993). Purification and characterization of 2,4-dichlorophenoxyacetate/ $\alpha$-ketoglutarate dioxygenase. J Biol Chem 268, 24311-24317.

Holtzhauer, M. \& Hahn, V. (1988). Biochemische Labormethoden: Arbeitsvorschriften und Tabellen, pp. 2-3. Berlin: Springer.

Horvath, M., Ditzelmüller, G., Loidl, M. \& Streichsbier, F. (1990). Isolation and characterization of a 2-(2,4-dichlorophenoxy)propionic acid-degrading soil bacterium. Appl Microbiol Biotechnol 33, 213-216.

Jin, Y. \& Cerletti, N. (1992). Western blotting of transforming growth factor $\beta 2$ : optimization of the electrophoretic transfer. Appl Theor Electrophor 3, 85-90.

Kaphammer, B., Kukor, J. J. \& Olsen, R. H. (1990). Regulation of $t f d C D E F$ by $t f d R$ of the 2,4-dichlorophenoxyacetic acid degradation plasmid pJP4. J Bacteriol 172, 2280-2286.

Kilpi, S. (1980). Degradation of some phenoxy acid herbicides by mixed cultures of bacteria isolated from soil treated with 2-(2methyl-4-chloro)phenoxypropionic acid. Microb Ecol 6, 261-270.

Lupi, C. G., Colangelo, T. \& Mason, C. A. (1995). Two-dimensional gel electrophoresis analysis of the response of Pseudomonas putida KT2442 to 2-chlorophenol. Appl Environ Microbiol 61, $2863-2872$.
Müller, R. H. \& Babel, W. (1986). Glucose as an energy donor in acetate growing Acinetobacter calcoaceticus. Arch Microbiol $144,62-66$.

Müller, R. H., Simon, D., Große, H. J. \& Babel, W. (1997). Substrate inhibition under stationary growth conditions - nutristat experiments with Ralstonia eutropha JMP134 during growth on phenol and 2,4-dichlorophenoxyacetate. Appl Microbiol Biotechnol 48, 648-655.

Müller, R. H., Jorks, S., Kleinsteuber, S. \& Babel, W. (1999). Comamonas acidovorans strain MC1: a new isolate capable of degrading the chiral herbicides dichlorprop and mecoprop and the herbicides 2,4-D and MCPA. Microbiol Res 154, 241-246.

Müller, R. H., Kleinsteuber, S. \& Babel, W. (2001). Physiological and genetic characteristics of two bacterial strains exhibiting activity of utilizing phenoxypropionate- and phenoxyacetateherbicides. Microbiol Res 156, 121-131.

Pemberton, J. M. \& Fisher, P. R. (1977). 2,4-D plasmids and persistence. Nature 268, 732-733.

Pieper, D. H., Reineke, W., Engesser, K.-H. \& Knackmuss, H.-J. (1988). Metabolism of 2,4-dichlorophenoxyacetic acid, 4-chloro2-methylphenoxyacetic acid, and 2-methylphenoxyacetic acid by Alcaligenes eutrophus JMP 134. Arch Microbiol 150, 95-102.

Schweigert, N., Zehnder, A. J. B. \& Eggen, R. I. L. (2001). Chemical properties of catechols and their molecular modes of toxic action in cells from microorganisms to mammals. Environ Microbiol 3, 81-91.

Uchiyama, H., Shinohara, Y., Tomioka, N. \& Kusaskabe, I. (1999). Induction and enhancement of stress proteins in a trichloroethylene-degrading methanotrophic bacterium, Methylocystis sp. M. FEMS Microbiol Lett 170, 125-130.

van Dyk, T. K., Majarian, W. R., Konstantinov, K. B., Young, R. M., Dhurjati, P. S. \& La Rossa, R. A. (1994). Rapid and sensitive pollutant detection by induction of heat shock gene-bioluminescence gene fusions. Appl Environ Microbiol 60, 1414-1420.

Vasseur, C., Labadie, J. \& Hébraud, M. (1999). Differential protein expression by Pseudomonas fragi submitted to various stresses. Electrophoresis 20, 2204-2213.

Received 30 November 2001; revised 15 February 2002; accepted 14 May 2002. 